tion .... and particularly with increased parental reaction and understanding."

\section{Therapeutic Considerations}

But while "evaluation of the family constellation in every child with a duodenal ulcer is part of therapy"12 it is by no means the whole therapy, because in psychosomatic disorder, management, like aetiology, is multifactorial and therefore governed by the principle of summation. In other words, psychotherapy, where it is pertinent, should never usurp the role of drugs, desensitization, diet, or other specific provisions; but equally, to be meaningful at all, management must embrace "psyche" as well as "soma," because the treatment schedules so involved are complementary-not mutually exclusive.

In migraine, this means combining specific therapy, such as ergotomine (in the prodromal phase of vasoconstriction), with adjunctive measures such as dietary restriction of tyraminecontaining foods, and psychotherapeutic buffering; in peptic ulcer, it means combining dietetic measures with appropriate drug therapy and emotional rehabilitation; while in asthma it means desensitizing where appropriate, combating secondary infection where suspected, prescribing chemotherapy as indicated, plus, once again (where relevant) psychodynamic intervention.

\section{Conclusion}

In every one of these "models," characterized by genetic vulnerability of the target organ, the overall aim should be reciprocal reinforcement of therapeutic benefit as opposed to unilateral preference for particular regimens. If it means anything at all, the psychosomatic concept discounts doctrinaire treatment of any kind in favour of the global approach.

\section{References}

1 Feldman, F., Cantor, D., Soll, S., and Bachrach, W., British Medical fournal, 1967, 3, 14

2 Pinkerton, P., fournal of Psychosomatic Research, 1967, 11, 11.

3 Pinkerton, P., in Psychotropic Drugs in Internal Medicine, ed. A. Pletscher, A. Marino, p. 115. Amsterdam, Excerpta Medica, 1969.

- Jones, R. S., British Medical fournal, 1966, 2, 972.

Weiner, H., Thaler, M., Reiser, M. F., and Mirsky, I. A., Psychosomatic Medicine, 1957, 19, 1.

- British Medical fournal, 1970, 1, 584

7 Graham, P. J., Rutter, M. L., Yule, W., and Pless, I. B., British fournal of Preventive and Social Medicine, 1967, 21, 78.

8 Leigh, D., and Marley, E., Bronchial Asthma, Oxford, Pergamon, 1967.

- Sultz, H. A., Schlesinger, E. R., Feldman, J. G., and Mosher, W. E., American fournal of Public Health, 1970, 60, 492.

10 Holguin, J., and Fenichel, G., Fournal of Pediatrics, 1967, 70, 290.

11 Pinkerton, P., Proceedings of the 4 th Union of European Pedopsychiatrists Congress, Stockholm.187, 1972 .

12 Muggia, A., and Spiro, H. M., Gastroenterology, 1959, 37, 715.

\title{
Transmission of Malaria
}

\section{5th Anniversary of Ronald Ross's Great Discovery}

\section{J. BRUCE-CHWATT}

\section{British Medical fournal, 1972, 3, 464-466}

This year on 20 August the world of tropical medicine honours one of its great men, Sir Ronald Ross, who seventy five years ago discovered the transmission of malaria by mosquitoes.

In England the disease was still common in the last century, particularly in the fenlands of the eastern counties. Even the emigrants to the backwoods of Canada and America knew it as "settlers' fever." In the hot countries of the tropics it was the prime killer both of the indigenous populations and of European traders and missionaries. Its treatment by quinine had been discovered as long ago as the 16th century, but its cause and nature had remained a mystery until in 1880 Laveran in Algeria found the parasite in the blood of patients with the disease. Now it remained to be discovered how man became infected, and it was not for another 17 years that the mystery yielded to the determination, tenacity, and skill of Ronald Ross (Fig. 1), a surgeon-major in the Indian Medical Service.

\section{Unchosen Career}

Ronald Ross was born on 13 May 1857 at Almora, India. His father was General Sir Campbell Claye Grant Ross, K.C.B., in command of the Afghan Frontier. Young Ronald spent his early childhood in India and came to England at the age of 8 to start his education. At 17, in obedience to his

London School of Hygiene and Tropical Medicine

L. J. BRUCE-CHWATT, M.D., Professor of Tropical Hygiene father's wishes, he entered St. Bartholomew's Hospital Medical School. The career was not of his choosing, for the young Ross was artistic and literary by inclination and had little real interest in science. Philosophy, poetry, music, and mathematics were his interests, and he attained high standards in all of them. Throughout his life they remained his constant source of joy and refreshment. Nevertheless, he obtained the Conjoint diploma and entered the Indian Medical Service

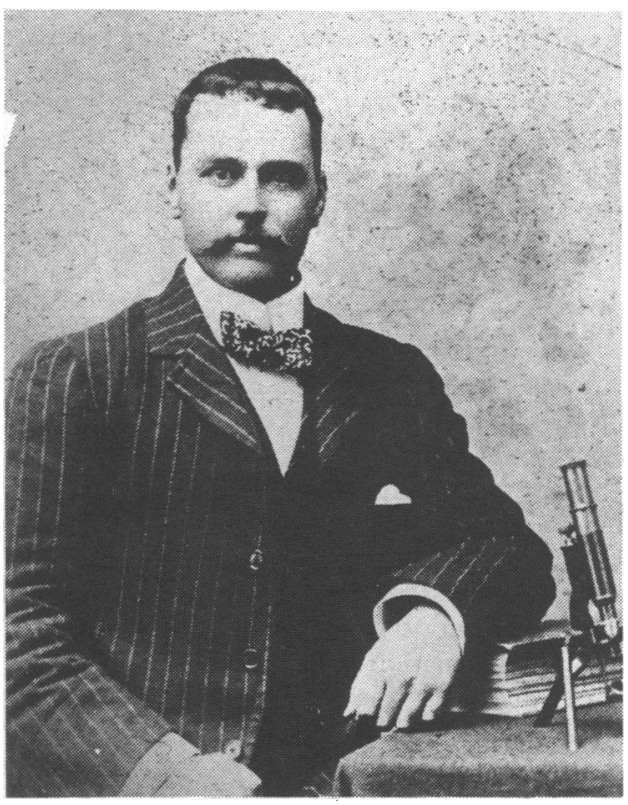

FIG. 1-Ronald Ross aged 41. 
in 1881. His experience in the wards of his Indian Hospital brought him to a new understanding of the importance of his calling, and he saw only too clearly that the vicious circle of disease, poverty, and ignorance was one of the main causes of the seemingly incurable misery in India. No disease was more involved than malaria, not only in its effects on sickness and mortality, but in lowering resistance to numerous other ills. He wrote:

The painful faces ask; can we not cure?

We answer, No not yet; we seek the laws.

$O$ God reveal through all this thing obscure

The small unseen, but million-murdering cause.

It was this conviction that brought him back to London in 1889 to attend the course in preventive medicine, and to seek the origins and causes of disease in the new science of bacteriology then being taught there.

Back in India he began to work seriously on the problem of malaria, but the first years were spent in fruitless searching. It was not until he came back to England on leave in 1894 that he found new inspiration to continue his work. He met Sir Patrick Manson, the father of modern tropical medicine, who had recently established the relationship of the mosquito to infection with filariasis. Manson encouraged young Ross to seek the answer to the problem of malaria, convinced that in this case too the mosquito transmitted the infection. He persuaded Ross that this was the most promising line of research and henceforth remained his most constant friend and guide.

\section{Hunt for Flagellum}

On his return to India Ross set to work on Manson's advice to "follow the flagellum"-the writhing thread-like proiection that burst from the parasite in the red blood cell. If the mosquito fed on infected man, surely the flagellum must be found in the mosquito. For two years Ross pored over his microscope in a vain effort to find the elusive flagellum. "The things are there, and must be found!" he wrote to Manson. Thousands of mosquitoes were painstakingly and delicately dissected, but their bodies revealed nothing. Ross could not know that he had not so far found the particular kind of mosquito that was responsible for transmission. It was not until he went with his regiment to Secunderbad in June 1897 that mosquitoes of the right kind, "the dappledwinged" Anopheles (later identified as Anopheles stephensi), were brought to him purely by chance. These he fed on infected patients and a few days later once more sat down to his microscope. And in these at last, in Secunderabad on 20 August 1897, he recognized the form that the malaria parasite takes in the stomach of an anopheles mosquito and the telltale specks of black pigment he had sought so long.

Further studies showed the development of the parasite within the mosquito to the point where the infective forms of plasmodia pack the salivary glands of the female mosquito ready to be injected into man. These final phases of the work were repeatedly delayed by the exigencies of the service and frequent transfers, and eventually, unable to continue work on human malaria, Ross made his decisive observations in Calcutta on the life cycle of the parasite of bird malaria.

His letter to Manson dated 22 August 1897 described in detail the observations made during the previous two days. Ross's report under the title: "On some Peculiar Pigmented Cells found in two Mosquitoes fed on Malaria Blood" was despatched to the British Medical fournal in September and was published on 18 December 1897 (Fig. 2).

\section{New Era}

Ross's discovery marked the beginning of a new era in tropical medicine, and he devoted his life to applying the results of it. The study of the mosquito soon showed where the Anopheles were likely to breed. Swamps, ponds, and puddles, however small, could harbour them and provide endless new swarms of potential carriers of malaria. Sanitation and drainage together with the destruction of larvae became the basis of control measures, which soon produced dramatic results wherever they could be applied. In 1899 Ross returned to England and became professor of tropical medicine

\section{ON SOME PECULIAR PIGMENTED CELLS FOUND IN TWO MOSQUITOS FED ON MALARIAL BLOOD.}

By SURgen-Major RONALD ROSS, I.M.S., (With Note by Surgeon-Major SMYTH, M.D., I.M.S.)

For the last two years I have been endeavouring to cultivate the parasite of malaria in the mosquito. The method adopted has been to feed mosquitos, bred in bottles from the larva, on patients having crescents in the blood, and then to examine their tissues for parasites similar to the hæmamoba in man. The study is a difficult one, as there is no a priori indication of what the derived parasite will be like precisely, nor in what particular species of insect the experiment will be successfal, while the investigation requires a thorough knowledge of the minute anatomy of the mosquito. Hitherto the species employed have been mostly brindled and grey varieties of the insect; but thongh I have been able to find no fewer than six new parasites of the mosquito, namely, a nematode, a fungus, a gregarine, a sarcosporidium (?), a coccidium (?), and certain swarm spores in the stomach, besides one or two doubtfully parasitic forms, I have not yet succeeded in tracing any parasite to the ingestion of malarial blood, nor in observing special protozos in the evacuations due to such ingestion. Lately, however, on abandoning the brindled and grey mosquitos and commencing similar work on a new, brown species, of which I have as yet obtained very few individuals, I succeeded in finding in two of them certain remarkable and suspicious cells containing pigment identical in appearance to that of the parasite of malaria. As these cells appear to me to be very worthy of attention, while the peculiar species of mosquito seems most unfortunately to be 80 rare in this place that it may be a long time before I can procure any more for farther study, I think it would be advisable to place on record a brief description both of the cells and of the mosquitos.

FIG. 2-From the British Medical foumal, 18 December, 1897.

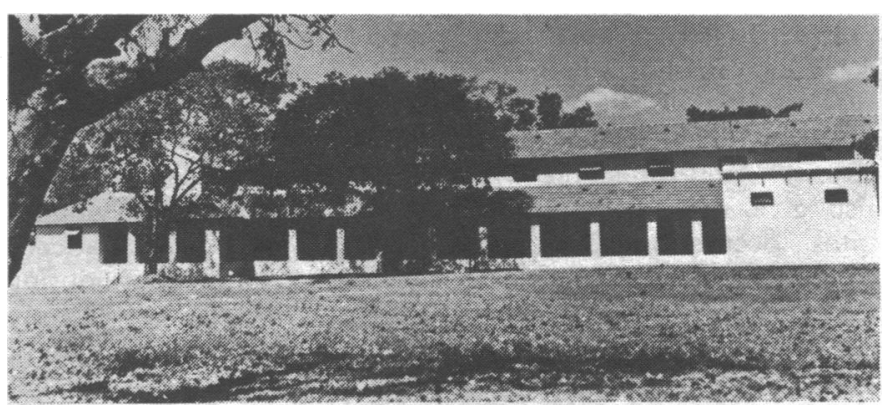

FIG. 3-Begumpet Hospital, Secunderabad (now the Deccan Airways Office), where the transmission of malaria by mosquitoes was discovered.

in Liverpool. In 1901 he was elected a Fellow of the Royal Society and a year later he received the Nobel prize. Many other British and foreign honours came to him during the next few years; he was made K.C.B. in 1911 and C.M.G. in 1918.

In 1926 after a strenuous campaign for public support he founded the Ross Institute of Tropical Hygiene at Putney Heath for teaching and research on the control of malaria and other communicable diseases. He died in 1932, and in 1934 the Ross Institute was incorporated into the London School of Hygiene and Tropical Medicine (University of London), where it functions as the department of tropical hygiene. The institute's activities at present cover a wide field of public health in developing countries, and its teachings and research work are of international repute.

The Begumpet Hospital in Secunderabad, where Ross 


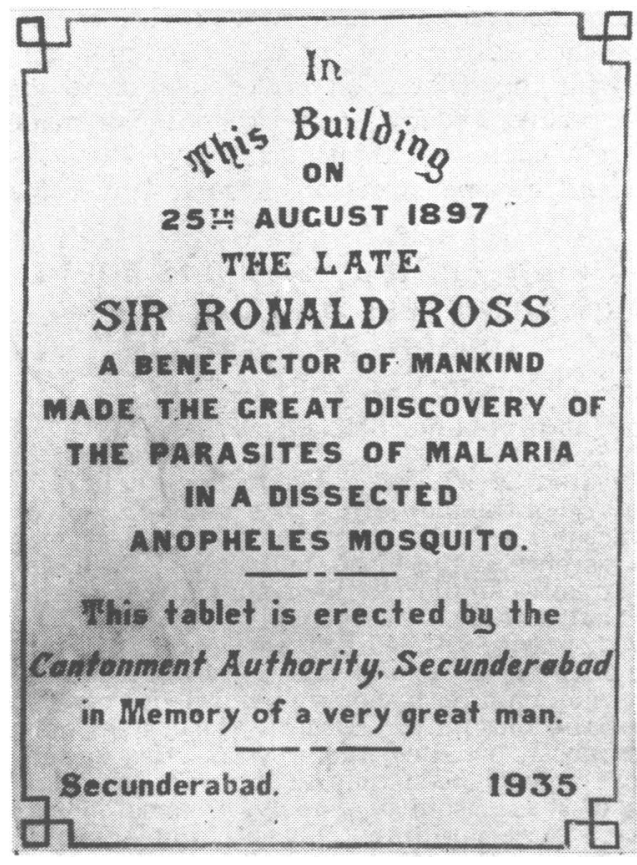

made his famous discovery 75 years ago, is still standing (Fig. 3). After the second world war it was taken over by the Indian Ministry of Communications. In 1935 a commemorative tablet (Fig. 4) was put up at the entrance to this building with a suitable inscription.*

Every year since 1957 the University of Hyderabad organizes on "Mosquito Day" an excursion to the place where Ross made his discovery. Lately these meetings, sponsored by the Indian Society of the History of Medicine, have aroused much interest among wide circles of the medical profession thanks to the active support of Major General S. L. Bhatia and Professor D. V. Subba Reddy.

An exhibition of rare photographs, letters, diaries, medals, and other items commemorating the 75th anniversary of Sir Ronald Ross's discovery of the transmission of malaria by mosquitoes is on display in the library of the London School of Hygiene and Tropical Medicine until 30 October.

FIG. 4-Commemorative tablet put up in 1935 at the entrance to the fortrance to the former Begumpet derabad.
* The choice of the date on the tablet (25 August 1897) is puzzling. On 24 August Ross dissected a few Anopheles culicifacies, but in contradistinction to his previous findings in $A$. stephensi could not find any trace of malaria infection in them. On 31 August he wrote to Sir Patrick Manson describing his work between 22 and 31 August. He made no reference to any events on 25 August and mentioned that he would soon be leaving for Bangalore, where Mrs. Ross and the children were staying. He himself left Secunderabad on 3 September.

\section{Any Questions?}

\section{We publish below a selection of questions and answers of general interest}

\section{Second Attack of Pertussis}

Is a second attack of whooping cough common in children, and does the lymphocyte count rise with the second attack?

Second attacks of whooping cough may occur during childhood but are uncommon. It remains to be established however whether Bordetella pertussis can cause two attacks of whooping cough in one individual since various adenoviruses $^{1-5}$ and infection with $B$. parapertussis infection can also give rise to the whooping cough syndrome. Lymphocytosis occurs in association with both $B$. pertussis and adenovirus whooping cough ${ }^{2}$ and therefore could occur during second attacks if the causative agents for two attacks are different. Lymphocytosis occurs also after administration of a first dose of pertussis vaccine in children ${ }^{6}$ and mice $^{7}$ but not after the second. The $B$. pertussis lymphocyte stimulating factor therefore is antigenic ${ }^{7}$ but its relationship with the protective factor is not clear.

1 Chany, C., Lepine, P., Lelong, M., Le-Tan-Vinh, Satge, P., and Virat, J., American fournal of Hiygiene, 1958, 67, 367.

2 Olson, L." C., Miller, G., and Hanshaw, J. B., Lancet, 1964, 1, 200. 3 Collier, A. M., Connor, J. D., Irving, W. R., fournal of Pediatrics, 1966, 69, 1073.

4 Connor J.' D., New England fournal of Medicine, 1970, 283, 390.

5 Pereira, M. S., and Candeias, J. A. N., Fournal of Hygiene, 1971,

69, 399. Fournal of the American Medical Association, 1933, $100,239$.

7 Morse, S. I., Journal of Experimental Medicine, 1965, 121, 49.

\section{Surgery for Thick Ankles}

A young woman with thick ankles is embarrassed by their appearance. Is surgical treatment feasible?

Surgery for thick ankles is unrewarding. The few patients for whom it can seriously be entertained are those with sofit, fluctuant, and well localized bulges, resembling a series of lipomata, all round the internal and external malleoli. The resemblance to lipomata is confirmed at operation, and the lumps of fat can be shelled out. No skin must be removed, and even then the wounds are tight on suture and tend to disrupt with early movement. Only one ankle should be operated on at a time, and there should be a good interval out of hospital between the two operations. The scars tend to be indifferent but the contour of the ankle most rewarding.

Patients who are not in the group described, and especially those whose reaction is out of proportion to their abnormality, should be treated as cases of adolescent depression. Long experience of collaboration with psychiatric colleagues has convinced me of the value in cosmetic problems of the skilled use of the antidepressant drugs. A patient who perseveres with this treatment learns to accept her deformity and live with it. The current fashion for trousers helps to lessen embarrassment.

\section{Notes and Comments}

Pink Napkins.-Dr. N. R. M. Buist (Department of Pediatrics, University of Oregon Medical School, Portland Oregon) writes: In answer to this question ("Any Questions?" 11 March, p. 683) your expert discusses the causes of pink napkins. In addition to the condition which he describes, it is possible that pink discolouration of the napkin can be caused by beeturia, a condition which occurs in some children after eating beetroots. More commonly uric acid crystals can also cause a pink staining of the napkins. This is often seen in the newborn but if it persists then the child should be investigated for uricosuria or hyperuricaemia. 